\title{
ORISINALITAS HUKUM ISLAM (Meretas Kontroversi Seputar Kelahiran Hukum Islam)
}

\author{
Muntaha Umar \\ (Fakultas Tarbiyah Universitas Islam Madura, Kompleks PP. Miftahul Ulum Bettet \\ Pamekasan, HP. 087750608080)
}

\begin{abstract}
Abstrak
Salah satu problem yang masih menjadi perdebatan di kalangan ahli hukum Islam adalah masalah kelahiran hukum Islam. Masalah tersebut telah memecah para ahli tersebut ke dalam dua kubu yang bertentangan. Kubu pertama berpendapat bahwa hukum Islam merupakan produksi para qadlî pada masa Bani Umayah. Argumentasi yang disuguhkan adalah bahwa Nabi Muhammad bukanlah seorang ahli hukum dan memang tidak meminati bidang ini. Sebaliknya, kubu kedua berpendapat bahwa hukum Islam sesungguhnya lahir pada masa Nabi Muhaammad dan bahkan diformulasikan sendiri olehnya. Perdebatan antara kedua kubu inilah yang hendak diperlihatkan dalam artikel ini disertai argumentasi yang mendasari kubu masing-masing dan kritik yang dilancarkan oleh keduanya. Pandangan kubu pertama bisa dipahami karena dalam mengembangkan tesisnya, ia tidak melihat alQur'an sebagai unsur yang patut diperhitungkan. Sebaliknya, kubu kedua mendasarkan tesisnya pada ayat al-Qur'an.
\end{abstract}

\begin{abstract}
One of the debatable problems among Islamic law experts is the origin of Islamic law. This separates them into two opponent sides. The first side argues that Islamic law was the product of qadli during the period of Bani Umayyah, they consider that the Prophet Muhammad was not a law expert and not interested in this field. The second group contrastively argues that Islamic law was originally appear during the Prophet Muhammad p.b.u.h period of time and he formulated it by himself. This article tries to describe debate of both side attached with argumentation and criticism relying them. View of the first group is understandable, because in developing his thesis, he did not see the Qur'an as an element to be reckoned. In contrast, the second group basing his thesis on the verses of the Qur`an.
\end{abstract}


Muntaha Umar

\section{Kata-kata Kunci}

Schacht, Goitein, hukum Islam, qadlî, Bani Umayah

\section{Pendahuluan}

Persoalan yang tetap hangat didiskusikan di kalangan para ahli keislaman, terutama para ahli hukum Islam di Barat, adalah mengenai eksistensi hukum Islam pada permulaan abad I $\mathrm{H}$. Persoalan tersebut adalah berkenaan dengan siapa yang bertanggung jawab sebagai agen yang menformulasikan hukum Islam tersebut ke dalam bentuk baku yang teraplikasikan ke dalam sebuah interaksi sosial yang bersifat mengikat. Snouck Hurgronje, yang terkenal sebagai pendiri kajian masalah-masalah hukum Islam di Barat, merupakan orang pertama yang mempertanyakan eksistensi hukum Islam dan meragukan peranan Nabi Muhammad sebagai orang yang paling bertanggung jawab terhadap formulasi hukum Islam tersebut. ${ }^{1}$ Ignaz Goldziher, melalui bukunya yang terkenal Muslim Studies, meragukan keaslian hadits Nabi dan mengklaim bahwa hadits-hadits tersebut merupakan produk abad II H. ${ }^{2}$ berdasarkan kajian yang dikembangkan oleh kedua ahli tersebut, Joseph Schacht, yang terkenal dengan dua karya monumentalnya, The Origins of Muhammadan Jurisprudence ${ }^{3}$ dan An Introduction to Islamic Law, ${ }^{4}$ mengajukan tesis bahwa hukum Islam mulai eksis pada abad II $\mathrm{H}$. Sedangkan orang yang paling berjasa atas perkembangan hukum Islam itu bukanlah Muhammad melainkan para qadlî yang ditunjuk oleh para gubernur pada masa pemerintahan Bani Umayyah. Para qadlî itulah yang mentransformasikan praktik-praktik administrasi yang populer pada masa Bani Umayyah tersebut ke dalam hukum Islam. ${ }^{5}$ Tesis ini, tentu saja, mendapat tantangan yang cukup serius dari kalangan ahli hukum Islam lainnya, baik dari para orientalis maupun Islam, seperti SD. Goitein, Wael B. Hallaq, dan MM. alAzami.

\footnotetext{
1 Salah satu karyanya adalah Selected Works of C. Snouck Hurgronje (Leiden: E.J. Brill, 1957)

2 Ignaz Goldziher, Muslim Studies, terj. S.M. Stern (London, 1967).

3 Dipublikasikan oleh Oxford: Clarendon Press, 1950.

${ }^{4}$ Dipublikasikan oleh Oxford: Clarendon Press, 1964.

${ }^{5}$ Joseph Schacht, An Introduction of Islamic Law (Oxford: Oxford University Press, 1959), hlm. 23-27.
} 
Tulisan ini merupakan sebuah "ijtihâd" untuk mengangkat masalah orisinalitas hukum Islam dengan membatasi diri pada kajian timing lahirnya dan peranan Nabi Muhammad dalam pembentukannya. Pembahasan ini akan bertumpu pada tesis dan argumentasi yang dikembangkan oleh Schacht dan pendukung teorinya, serta kontra argumen yang dikembangkan oleh para ahli hukum Islam yang menentang tesis tersebut. Selanjutnya, tulisan ini akan mencoba melihat kekuatan dan kelemahan masing-masing argumentasi sehingga akan diperoleh sebuah kesimpulan akhir.

\section{Nabi Muhammad dan al-Qur'an}

Tesis yang dikembangkan oleh Schacht merupakan hasil kajian historis yang dilakukan terhadap peranan Nabi Muhammad dan fungsi al-Qur'an pada masyarakat Muslim pada abad I H. Menurut Schacht, Muhammad ketika ada di ekkah memproklamasikan dirinya sebagai "pembawa pesan dari Allah" dan ia sangat keberatan ketika kaum kafir Quraysy menuduhnya sebagai kahin. Sebab di mata mereka, Muhammad ketika menuturkan ayatayat al-Qur'an tidak lebih dari para dukun yang membaca mantera dan jampi-jampi. Begitu juga peran yang dijalankan oleh Muhammmad sebagai penengah terhadap berbagai kasus yang terjado di tengah-tengah masyarakat, tidak lebih sama dengan peran para kahin di masyarakat jahiliyah. Salah satu contoh yang dikemukakan Schacht adalah peran sebagai hakam dalam kasus perkawinan (QS. 4: 35) yang dipraktikkan oleh Muhammad adalah sama dengan fungsi kahin dalam masyarakat Arab praIslam.

Penolakan Muhammad atas tuduhan sebagai kahin bukannya tanpa alasan. Muhammad, menurut Schacht, tidak ingin membatasi dirinya hanya sebagai hakam atau arbitrator dalam komunitasnya, tetapi ia mempunyai ambisi politik yang kuat yang berhasil diraihnya setelah berimigrasi ke Madinah. Di sana Muhammad membangun sebuah masyarakat baru yang merupakan batu loncatan untuk memenuhi ambisi politiknya. Karenanya, Muhammad pada dasarnya lebih tertarik pada masalah-masalah politik ketimbang pada masalahmasalah hukum. Bahkan, lanjutnya, otoritas Muhammad bukanlah 
pada masalah-masalah hukum, namun hanya berkaitan dengan masalah-masalah religius dan politik. ${ }^{6}$

Pernyataan tersebut senada dengan Ignaz Goldziher yang menggambarkan bahwa ketika di Madinah pun, Muhammad tidak menghentikan kegiatannya sebagai pemberi peringatan, namun kerasulannya mengalami bentuk baru. Muhammad tidak lagi sematamata sebagai penyampai wahyu. Perubahan situasi menjadikannya sebagai penyerang, penakluk, dan kepala negara. Ia mengorganisasikan sebuah masyarakat baru yang sedang berkembang. Islam sebagai sebuah institusi mengambil bentuk baru di Madinah. Di sinilah untuk kali pertama bentuk masyarakat Islam, hukum, dan aturan-aturan politik mulai terlihat. ${ }^{7}$

Guna meraih ambisi dalam karis politiknya, Muhammad, menurut Schacht, membutuhkan sebuah sistem yang merupakan kombinasi antara tugas-tugas hukum dan kewajiban-kewajiban moral yang digherakkanoleh semangat agama. Dalam hal ini, Islam merupakan sebuah sarana yang tepat yang digunakan oleh Muhammad sebagai seorang Nabi untuk menjelaskan misi yang diembannya kepada umat, menyeru mereka untuk menyelamatkan hidup mereka di dunia dan akhirat. Pada masa itu Muhammad tidak memerlukan sistem hukum yang mapan. Yang diperlukan hanyalah ajaran-ajaran agama dan prinsip-prinsip etika. Karenanya, Muhammad tidak punya alasan untuk mengganti hukum-hukum yang telah ada ketika itu. ${ }^{8}$ Hal ini dimungkinkan karena Muhammad memang berkepentingan terhadap masalah-masalah hukum.

Hal tersebut sesuai dengan pernyataan Hurgronje bahwa Muhammad memang sadar betul bahwa ia tidak mempunyai kualifikasi yang cukup untuk menangani masalah-masalah hukum, kecuali keadaan memang benar-benar mendesak. ${ }^{9}$ Emile Tyan juga mengatakan bahwa ketika seseorang menelitik hasil kerja Muhammad, ia akan sangat mudah yakin bahwa Muhammad memang tidak bermaksud untuk membentuk sebuah sistem hukum

6 Ibid., hlm. 11

7 Ignaz Goldziher, Introduction to Islamic Theology and Law (New Jersey: Princeton University Press, 1981), hlm. 8.

8 Schacht, An Introduction, hlm. 11.

${ }_{9}^{9}$ C. Snouck Hurgronje, Muhammadanism (1916), hlm. 60. 
yang baru, dan tidak pula untuk memperkenalkan sebuah sistem legislasi yang baru. ${ }^{10}$

Keengganan Muhammad tersebut dibuktikan dengan adanya elemen-elemen pinjaman dari luar ajaran yang dikembangkannya. Sebagai contoh adalah larangan untuk mengambil riba yang secara jelas diinspirasikan oleh pergaulannya dengan kalangan Yahudi di Madinah, bukan karena refleksi dari praktik dagang orang-orang Mekkah. Contoh lain adalah diteruskannya prinsip-prinsip retaliasi terhadap pembunuhan dan pencacatan badan (QS. 5: 48) yang didasari oleh Perjanjian Lama Yahudi (Exod. 21.23-25; Lev.24.19; Deut. 12.21). ${ }^{11}$

Al-Qur'an sendiri, menurut Schacht, memberikan indikasi atas ambisi Muhammad melalui ayat-ayat hukumnya. Al-Qur'an semata-mata menfokuskan dirinya pada etika dan norma hukum, seperti anjuran untuk memenuhi kontrak dan perjanjian yang telah disetujui, memberikan kesaksian, larangan menipu, dan sebagainya. Al-Qur'an tidak menjelaskan lebih lanjut akibat-akibat hukum dari sebuah tindakan yang tergambar dengan jelas di dalamnya. Teks alQur'an tidak mengelaborasi pertanyaan-pertanyaan seperti tanggung jawab sipil dan juga tidak memberikan konfirmasi terhadap tindakan yang sesuai dengan hukum atau pun berlawanan dengan hukum, kecuali ancaman neraka terhadap orang-orang yang berbuat dosa. ${ }^{12}$

Sebagai contoh etika al-Qur'an terhadap masalah-masalah hukum adalah ajarannya tentang kontrak. Dalam ajaran ini al-Qur'an hanya mengulang apa yang telah ada dalam masyarakat Arab pra Islam seperti menuliskannya sebuah perjanjian, menghadirkan saksi atau memberikan garansi apabila tidak ada saksi, memerintahkan seseorang untuk memenuhi kontrak yang telah disetujui, dan mengembalikan amanah kepada pemiliknya. Sejalan dengan itu, alQur'an juga memperkenalkan hukum perang yang dalam skala besar masih sejalan dengan kebiasaan pra-Islam. Di samping itu, al-Qur'an memperkenalkan hukum keluarga pada ayat-ayat yang berjumlah

10 Schacht, An Introduction, hlm. 13.

11 Schacht, "Foreign Element in Ancient Islamic Law", Journal of Comparative Legislation and International Law 32 (1950): 9-17.

12 Schacht, An Introduction, hlm. 12. 
cukup banyak, tetapi perhatian utama yang diberikan oleh al-Qur'an adalah mengatur wanita, anak-anak, anak yatim, sanak famili, orangorang terlantar, dan para budak. ${ }^{13}$

Berdasarkan beberapa penjelasan di atas, seseorang dapat berasumsi bahwa sikap hukum dari al-Qur'an dan ambisi politik pada diri Muhammad berjalan seiring. Yang pertama bertujuan memperbaiki perlakuan yang tidak manusiawi pada wanita, anakanak, dan anak yatim, lalu mengikis habis kebiasaan-kebiasaan masyarakat Arab pra-Islam seperti judi, ribâ, dan alkohol serta memberikan solusi terhadap masalah-masalah baru yang timbul dalam masyarakat. Semua itu bertujuan memberikan fasilitas yang memadai terhadap tujuan politik Muhammad dan menggantikan struktur masyarakat Jahiliyah dengan masyarakat Islam. Karenanya, dapat disimpulkan bahwa Muhammad sama sekali tidak berperan dalam pembentukan hukum Islam. Bukti-bukti menunjukkan bahwa Muhammad tidak berusaha untuk menghasilkan sebuah sistem hukum yang komprehensif. Ia hanya berpuas diri dengan meneruskan hukum-hukum adat yang telah eksis ketika itu. ${ }^{14}$

\section{Perkembangan Hukum Islam pada Periode Bani Umayyah}

Untuk mendukung teorinya, Schacht mengajukan argumen lain yakni deskripsi situasi yang terjadi setelah Muhammad wafat, ketika kekuasaan dipegang oleh para khalifah yang bertindak sebagai penetap hukum dalam masyarakat. Ketika itu, para khalifah tidak menunjuk qadlî dan tidak pula meletakkan fondasi yang nantinya dapat dijadikan dasar bagi sistem peradilan Islam. Yang mereka lakukan adalah meneruskan modifikasi dan kompilasi atas sistem arbitrasi Arab pra-Islam. Juynboll, yang selalu mendukung teori Schacht, menjelaskan bahwa keempat khalifah Islam menetapkan sebuah sistem meurut standar mereka masing-masing. Mereka mengatur masyarakat Islam dengan semangat kerasulan, tetapi mereka menyelesaikan masalah-masalah yang timbul menurut jalan pikiran masing-masing, tidak mencontohkan apa yang telah

\footnotetext{
${ }^{13}$ Ibid.

14 J.N.D. Anderson, “Recent Development in Shari'a Law”, Muslim Law 40 (1950), hlm. 245.
} 
dipraktikkan oleh Muhammad. ${ }^{15}$ Contohnya adalah diberlakukannya hukuman cambuk terhadap pengarang puisi yang isiya menyerang suku lain serta hukuman lempar batu sampai mati terhadap pelaku zina. ${ }^{16}$

Dinasti Bani Umayyah menggantikan fungsi kekhalifahan di Madinah pada pertengahan abad I H. Oleh Schacht, periode ini dipandang sebagai periode yang sangat menentukan dalam perkembangan hukum Islam. Sesungguhnya, Dinasti Bani Umayyah tidak terlalu memberikan perhatian pada agama dan perangkat hukumnya. Mereka lebih menfokuskan diri pada administrasi bidang politik. Begitu juga, mereka bertanggung jawab atas perkembangan sejumlah upacara keagamaan dan peribadatan yang sebelumnya masih dalam tahap pertumbuhan. ${ }^{17}$

Dinasti Bani Umayyah dalam menghadapi perang terhadap musuh-musuhnya menetapkan regulasi dan administrasi hukum seperti hukum perang dan administrasi keuangan. Salah satu contohnya adalah pemberlakuan terhadap sepertiga dari kepemilikan. Artinya, apabila seseorang meninggal dunia tanpa diketahui ahli warisnya, maka sepertiga dari hartanya diserahkan kepada bayt al-mal. 18

Mereka juga mengambil langkah yang sangat signifikanterhadap administrasi hukum dengan mengangkat para qadlî. Para gubernur pada masa itu berkuasa pada tingkat provinsi. Mereka mendelegasikan kekuasaan kehakiman kepada pra qadlî sebagai pembentuk hukum yang hanya berlaku atas kaum Muslim saja. Dalam mengambil keputusan hukum, yang nantinya menjadi dasar dari hukum Islam, para qadlî tersebut menggunakan daya kreasi mereka dengan jalan mengkombinasikan hukum setempat dengan semangat al-Qur'an dan norma-norma hukum kontemporer dalam masyarakat Muslim.

15 G.H.A. Juynboll, Muslim Tradition: Studies Chronology, Provenance and Authorship of Early Hadith (Cambridge: Cambridge University Press, 1983), hlm. 15.

16 Menurut Schacht hukuman ini tidak tercantum di dalam al-Qur'an dan jelas diambil dari hukum Nabi Musa. Lihat Schacht, An Intriduction, hlm. 15.

17 Ibid., hlm. 23.

18 Ibid., hlm. 24. 
Tugas itu, menurut Schacht, dalam perjalanan selanjutnya menjadi semakin berat dan membutuhkan tenaga spesialis dalam bidang hukum. Mereka adalah orang-orang yang tertarik pada masalah-masalah hukum tetapi tidak terdidik secara khusus dalam bidang hukum. Dengan mengkaji hukum adat setempat dalam perspektif al-Qur'an dan norma-norma Islam, pada puncaknya mereka berhasil menetapkan apa yang disebut dengan "jalan hidup Islami". Mereka juga mensurvei lapangan hukum, termasuk administrasi dan praktik-praktik hukum yang populer, mengambil yang layak diterima, memodifikasi dan menolak yang tidak sesuai. Hasil kerja mereka kemudian ditransformasikan ke dalam hukum Islam.

Ibrahim al-Nakha'i dari Kufah adalah salah seorng spesialis dalam hukum Islam. Ia memberikan respon atas berbagai masalah peribadatan dan keluarga, tetapi tidak dalam hal-hal yang bersifat teknis. Dengan kata lain, mereka bertindak semata-mata sebagai mufti yang terkadan memberikan kritik terhadap berbagai peraturan dalam pemerintahan Bani Umayyah. Berdasarkan uraian di atas, Schacht menyimpulkan bahwa hukum Islam berasal dari periode Bani Umayyah. ${ }^{19}$

\section{Antara Schacht dan Goitein}

Tesis yang dikembangkan oleh Schacht cukup mengagetkan para ahli hukum Islam, baik di Barat maupun di Timur. Hal ini dapat dimengerti karena tesis ini baru terdengar pada abad XIX $M$. Sebelumnya sudah baku dan mapan di kalangan kaum Muslim bahwa sejak Nabi Muhammad diutus, saat itu juga hukum Islam, sebagai hukum yang berasal dari Allah, telah diturunkan dan sudah mulai duterapkan secara perlahan-lahan dan bertahap, baik yang bersifat ritual maupun sosial, seperti hukum pidana da perdata. Keyakinan tersebut tentu saja berdasarkan fakta-fakta yang termaktub dalam al-Qur'an dan Sunnah Rasulullah.

Mengapa Schacht mencapai kesimpulan yang sangat bertentangan dengan pandangan umum di kalangan kaum Muslim? Jawabannya adalah karena Schacht melepaskan dirinya dari kajian yang bersifat teologis maupun yuristik, serta menggantikannya

19 Ibid., hlm. 27. 
dengan kajian yang bersifat sosiologis. Sebagaimana yang diungkapkan oleh Layish bahwa Schacht memperlakukan hukum Islam bukan sebagai kesatuan norma-norma hukum, tetapi sebagai fenomena sejarah yang berkaitan erat dengan kenyataan sosial. ${ }^{20}$ Ia juga menekankan bahwa hukum Islam, termasuk sumber-sumbernya, merupakan hasil dari proses perkembangan sejarah. ${ }^{21}$

Tesis yang dikembangkan oleh Schacht ini tidak dapat bertahan lama, karena para sarjana yang melakukan penelitian menemukan banyak kelemahan pada tesis tersebut. Kesalahan metodologis yang paling mendasar yang dilakukan oleh Schacht dalam menformulasikan tesisnya, menurut MM.al-Azami, adalah ketidakpedualiannya atas bukti-bukti yang terdapat di dalam alQur'an yang berkaitan dengan ajaran-ajaran hukum.22 Padahal, buktibukti menunjukka bahwa para ahli hukum dalam mengatasi sejumlah besar pertanyaan yang muncul selalu mendasarkan dirinya pada ketentuan al-Qur'an serta berangkat dari stimulasi yang ada pada ayat-ayat al-Qur'an tersebut. Berdasarkan bukti-bukti tersebut Zafar Ishaq Anshari mengklaim bahwa al-Qur'an sebagai sumber hukum yang mengikat telah mapan sejak sebermula. ${ }^{23}$

Bukan hanya sikap Schacht terhadap al-Qur'an yang dikecam, idenya tentang peran Muhammad juga mendapat mendapat sorotan yang cukup tajam. SD. Goitein menunjukkan bahwa tesis yang dikembangkan oleh Schacht itu secara historis sulit untuk diterima. Goitein mencoba membuktikan apakah syari'ah itu memang dapat ditelusuri ke arah pendirinya, yaitu Muhammad. Jika dapat, kapan aktifitas itu dapat dibuktikan? Untuk menjawab pertanyaan ini, ia mendasarkan pembahasannya pada ayat al-Qur'an, suatu sikap yang

\footnotetext{
20 Aharon Layish, "Notes on Joseph Schacht's Contribution to the Study of Islamic Law", British Society Middle Eastern Studies, Bulletin 9 (1982), hlm. 133.

${ }^{21}$ David F. Forte, "Islamic Law: The Impact of Joseph Schacht", Loyola of Los Angeles International and Comparative Law Annual 1 (1978), hlm. 9.

22 M.M. al-Azami, On Schacht's Origins, hlm. 17.

${ }^{23}$ Zafat Ishaq Anshari," The Early Development of Islamic Fiqh in Kufah with Special Reference to the Works of Abu Yusuf and Shaibani", Ph.D. Diss., McGill University, 1966.
} 
tidak ditemukan pada diri Schacht, dan peristiwa bersejarah pada era awal di Madinah. ${ }^{24}$

Tentang Muhammad sebagai pencetus hukum, Goitein mempunyai pendapat yang berbeda. Menurutnya, ketika berada di Makkah, Muhammad bertindak semata-mata sebagai khatib dan nabi. Namun, di Madinah tuntutan dari masyarakat yang sedang berkembang memaksanya untuk memberikan keputusan-keputusan hukum dari masa ke masa. Lebih lanjut dikatakan bahwa Muhammad di Madinah mempunyai kemampuan untuk mengorganisasikan seluruh penduduk kota, Muslim dan non-Muslim, sebagai sebuah kesatuan badan politik. Untuk mempertahankan kesatuan ini Muhammad membuat konstitusi yang terdiri dari 47 paragraf. Di samping itu, banyak lagi perjanjian yang ditandatangani dengan sesama suku-suku Arab lainnya. Hal ini menunjukkan bahwa Muhammad telah berkecimpung dengan masalah-masalah hukum. Sejalan dengan hal di atas, Goitein yakin bahwa banyak pertanyaan hukum yang telah diajukan kepada Muhammad dan diputuskan olehnya ketika itu juga. 25

Merupakan tradisi bagi bangsa Arab bahwa orang yang bertindak sebagai hakim bukanlah kepala suku atau pun orang yang berkuasa. Tetapi orang bijak, yang terkadang berdiam jauh terpencil dari kota, yang terkenal dengan inspirasi yang akurat dan pengalaman yang cukup. Sebuah contoh yang dikemukakan oleh Goitein adalah salah seorang ketua kelompok dari Yahudi 'Aqil di Yaman telah didekati oleh para ketua suku Arab untuk mengatasi perselisihan di antara mereka. Hal yang sama, Ka'b ibn al-Ashaf, salah seorang tokoh Yahudi Madinah, ditugaskan untuk menangani perkara-perkara non-Yahudi. Begitu pula pula, Muhammad merupakan tokoh spiritual yang diakui dan menurut konsep Arab, ia harus bertindak sebagai hakam bagi kaum Muslim maupun nonMuslim, termasuk Yahudi. Walaupun mereka sendiri sesungguhnya memiliki tokoh sendiri seperti rabbaniyyun dan ahbar yang menangani masalah-masalah hukum di kalangan mereka. ${ }^{26}$

${ }^{24}$ D. Goitein, "The Birth-Hour of Muslim Law”, Muslim World, vol. 50, 1 (January, 1960), hlm. 23-29.

25 Ibid., hlm. 25.

26 Ibid. 
Pertanyaan yang timbul kemudian adalah mengapa begitu sedikit keputusan hukum Nabi Muhammad yang dimasukkan ke dalam sûrah-sûrah pada awal-awal periode Madinah. Goitein menjawab bahwa perkara-perkara itu terjadi pada akhir periode Madinah. Untuk membuktikannya, Goitein mengutip surat al-Maidah 42-51. Dalam ayat 42-43 Nabi Muhammad mengekspresikan keheranannya terhadap kaum Yahudi Madinah yang menjadikannya hakim, padahal mereka mempunyai kitab hukum sendiri.

Sebelum beberapa ayat tersebut diturunkan, ada kecederungan di kalangan kaum Yahudi Madinah, setelah meminta keputusan dari Nabi Muhammad, mereka tidak sepakat mnerima keputusan tersebut. Bahkan meurut Goitein, di kalangan kaum Muslim saat itu muncul sikap kritis yang ditujukan pada keputusan yang ditetapkan oleh Nabi Muhammad. Sikap seperti ini sangat membahayakan hubungan antara kepemimpinan spiritual dan fungsi sebagai hakim. Tampaknya, waktu itu, Nabi Muhammad belum menjadikan keputusan-keputusannya sebagai bagian dari tugasnya sebagai rasul. Dengan turunnya ayat-ayat tersebut, situasi itu harus diubah. Semua keputusan hukum yang ditetapkan oleh Nabi Muhammad dianggap bersangkut-paut dengan sikap keberagamaan seseorang, sama dengan kepercayaan kepada Allah dan hari kebangkitan. Karenanya, ayat-ayat ini kemudian diikuti dengan larangan untuk mengambil orang-orang Yahudi dan Nasrani sebagai pemimpin, masing-masing komunitas dipandang sebagai satu kesatuan yang komplit dan terpisah. ${ }^{27}$

Turunnya kelompok ayat ini dipandang oleh Goitein sebagai titik dari kesadaran Muhammad terhadap perlunya mempunyai satu sistem hukum sendiri. Karenanya, ia menjadikan ayat ini sebagai awal lahirnya hukum Islam. Tesis ini, tentu saja, bertentangan dengan tesis yang dikembangkan oleh Schacht. Goitein kemudian melakukan penelitian atas asbâb al-nuzul dari ayat-ayat tersebut dengan mempertimbangkan bahwa referensi yang dipergunakan al-Qur'an terhadap para rabbi Yahudi hanya cocok ketika Yahudi masih eksis di Madinah dalam jumlah yang banyak. Penelitian ini membawanya

27 Ibid., hlm. 25. 
pada sebuah kesimpulan bahwa ayat-ayat tersebut turun pada tahun kelima Hijriyah atau lima tahun sebelum Nabi Muhamad wafat. Kesimpulan yang sama juga dapat dirujuk pada al-Zuhrim al-Waqidi dan al-Thabari. Berdasarkan hal itu, ia berpendapat bahwa hukum Islam itu telah eksis pada abad kelima Hijriyah. ${ }^{28}$

Sejalan dengan argumentasi yang diajukan oleh Goitein, Wael B. Hallaq mengajukan bukti lebih lanjut terhadap aktifitas hukum yang disebut ifta' (meminta atau memberi fatwa). Menurutnya, pada awal abad pertama Hijriyah, aktifitas hukum muncul dalam bentuk fatwa, sebuah fenomena yang wajar mengingat sebagai agama yang masih muda Islam sangat bergantung pada pengarahan dari para ahli terbaik dalam bidang hukum yang tidak lain adalah para mufti. Hallaq mengklaim bahwa tidak lebih dari 130 sahabat Nabi yang dapat dihubungkan dengan aktifitas fatwa dan beberapa di antaranya mengkhususkan diri secara mendalam mengeluarka fatwa..$^{29}$

Dalam mengajukan pendapatnya, Hallaq membawa bukti dari ayat-ayat al-Qur'an yang berhubungan dengan fatwa. Contohnya adalah yas'alunaka (mereka bertanya kepadamu (Muhammad)), yastaftunaka (mereka meminta fatwa kepadamu), atau iftina (berilah fatwa kepada kami). Semua ini tercantum di dalam al-Qur'an tidak kurang dari 126 kali baik di surat Makkiyah maupun Madaniyah. Walaupun ayat Makkiyah tidak menerangkan masalah hukum, tetapi ayat Madaniyah penuh dengan masalah-masalah hukum. Karenanya, Hallaq berpendirian bahwa argumen-argumen di atas memaksa kita untuk meninjau kembali argumen yang diajukan oleh Schacht bahwa al-Qur'an memainkan peranannya sebagai sumber hukum pada akhir abad pertama Hijriyah. Hal ini disebabkan oleh argumen di atas telah menunjukkan fakta yang jelas bahwa hukum-hukum di dalam alQur'an telah mengakar pada fase Madinah dalam karir Nabi Muhammad, pada fajar abad pertama Hijriyah. ${ }^{30}$

\footnotetext{
28 Ibid.

29 Wael B. Hallaq, "From Fatwas to Furu': Growth and Chabge in Islamic Substantive Law" Islamic Law and Society, 1, (1994), hlm. 1-33.

30 Ibid., hlm. 33.
} 


\section{Penutup}

Dari uraian di atas dapat disimpulkan bahwa hukum Islam menurut Schacht lahir pada masa pemerintahan Bani Umayah. Pandangan ini bisa dipahami karena dalam mengembangkan tesisnya, ia tidak melihat al-Qur'an sebagai unsur yang patut diperhitungkan. Ia meletakkan al-Qur'an sebagai alternatif kedua dalam konteks hukum di masyarakat Islam saat itu. Sebaliknya, Goitein berpendirian bahwa hukum Islam itu telah eksis pada abad kelima Hijriyah. Ia mendasarkan tesisnya pada ayat al-Qur'an, suatu sikap yang tidak ditemukan pada diri Schacht, dan peristiwa bersejarah pada era awal di Madinah.

\section{Daftar Pustaka:}

Anderson, J.N.D. "Recent Development in Shari'a Law”, Muslim Law 40 (1950)

Anshari, Zafat Ishaq. " The Early Development of Islamic Fiqh in Kufah with Special Reference to the Works of Abu Yusuf and Shaibani". Disertasi Ph.D. McGill University, Kanada, 1966.

Forte, David F. "Islamic Law: The Impact of Joseph Schacht". Loyola of Los Angeles International and Comparative Law Annual 1 (1978)

Goitein, D. "The Birth-Hour of Muslim Law", Muslim World, vol. 50, 1 (January, 1960)

Goldziher, Ignaz. Introduction to Islamic Theology and Law. New Jersey: Princeton University Press, 1981.

Goldziher, Ignaz. Muslim Studies. terj. S.M. Stern .London, 1967.

Hallaq, Wael B. "From Fatwas to Furu': Growth and Chabge in Islamic Substantive Law" Islamic Law and Society, 1, (1994)

Hurgronje, C. Snouck. Selected Works of C. Snouck Hurgronje. Leiden: E.J. Brill, 1957.

Juynboll, G.H.A. Muslim Tradition: Studies Chronology, Provenance and Authorship of Early Hadith. Cambridge: Cambridge University Press, 1983.

Layish, Aharon. "Notes on Joseph Schacht's Contribution to the Study of Islamic Law". British Society Middle Eastern Studies, Bulletin 9 (1982). 
Schacht, Joseph. "Foreign Element in Ancient Islamic Law". Journal of Comparative Legislation and International Law 32 (1950)

Schacht, Joseph. An Introduction of Islamic Law. Oxford: Oxford University Press, 1959. 